\title{
A conspectus of orchid studies in India
}

\author{
Adit A. ${ }^{1}$, Jalal J.S. ${ }^{2}$, Koul M. ${ }^{3}$ \& R. Tandon ${ }^{1 *}$ \\ ${ }^{1}$ Department of Botany, University of Delhi, Delhi - 110 007, India \\ ${ }^{2}$ Western Regional Centre, Botanical Survey of India, Pune, Maharashtra - 411001 , India \\ ${ }^{3}$ Department of Botany, Hans Raj College, University of Delhi, Delhi - 110007 , India \\ *E-mail: tandon.raj@gmail.com
}

\begin{abstract}
Orchidaceae represents the largest family of flowering plants in India. The country has come a long way from an era of exploration phase, identification and preparation of inventories of orchids, yet it appears to be an unfinished endeavour. Besides documenting the ethnobotanical knowledge of various orchid species, in vitro tissue regeneration, micropropagation, and cell culture protocols have also been standardised for many orchid species. However, in contrast to the available diversity, ecological and molecular studies of orchids have not been conducted extensively in the country. Although above (pollinators) and below ground (fungal endophytes) mutualists have been recorded for few orchid taxa, the underlying functional mechanisms, which facilitate the processes, are unexplored. The present review offers insights into the major works that have been carried out on orchids in India, and also highlights several areas of potential research that are neglected or understudied. Most importantly, there is a need to broaden the objectives while training orchidologists. It appears that unification of subdisciplines is a priority in orchid biology in general, and conservation in particular.
\end{abstract}

Keywords: Conservation, Ecology, Mycorrhizae, Pollination, Taxonomy, Tissue culture.

\section{Introduction}

With more than 28,000 species, Orchidaceae is one of the largest families in the plant kingdom and are known to occupy a variety of niches with habitats ranging from terrestrial to epiphytic and even underground (Christenhusz \& Byng, 2016). An estimated one out of every ten flowering plant is

Received: 31.03.2021; Revised \& Accepted: 06.09.2021

Published Online: 16.10.2021 an orchid (Gentry \& Dodson, 1987). In contrast to its diversity, only a small proportion of orchids have been studied so far (Tandon \& Bhardhwaj, 2012). Due to the enormous variability in structural as well as functional traits, orchids are now considered as model system to study complexity and variability (Edens-Meier \& Bernhardt, 2014).

With more than $9 \%$ of the angiosperm flora, orchids form the largest group of plants in India (Adit et al., 2020). Ethnobotanical uses of orchids have been well documented in the country (Rajendran et al., 1997; Chowlu et al., 2013; Panda \& Mandal, 2013). While floristic and propagation studies on orchids have been popular, research on functional and molecular biology is insufficiently pursued. Change in climate regimes, habitat destruction, fragmentation, and aggressive collection from the wild have made visible adverse impacts on the native orchid flora (Jalal, 2012; Medhi et al., 2012). Integrative understanding of taxonomy and ecology of orchids, using conventional, molecular and in vitro techniques will aid in conservation of orchids and develop site-specific strategies for their conservation.

Here, we (i) attempt to compile and highlight the aspects of orchidology in India, and (ii) reiterate core areas of biological studies that can play a crucial role in the development of conservation practices.

\section{Systematic biology}

The first record on Indian orchids come from Ayurvedic texts. The medicinal value of some orchids including Eulophia dabia (D.Don) Hochr., Flickingeria nodosa (Dalzell) Seidenf. and Malaxis 
rheedei Blume find their mention in the classical Indian medicinal treatise Charaka Samhita from around 100 AD (Caraka et al., 2017). Indian orchids were formally introduced to the western world by the Dutch Governor of Malabar (van Rheede, 1692, 1693), in which 17 orchid taxa were described in detail. Based on Rheede's descriptions, Linnaeus (1753) assigned binominals to many plants including orchids and treated them in his genus Epidendrum L. Two genera of ornamental plants, namely Cymbidium Sw. and Rhynchostylis Blume, were also established solely based on Rheede's illustrations. Linnaeus (1753) included 12 orchid species from the Indian sub-continent. Later, Roxburgh (1832) recorded 57 species of orchids belonging to eight genera and proposed many new taxa, which were later re-assigned to other genera based on various floral traits.

During the pre-independence period, significant work on orchids in India was carried out by the following: Griffith (1851) provided an extensive account on the general morphology, methods of pollination and affinities of each of 147 species in 49 genera. However, the most significant contributions about Indian orchids was made by Hooker $(1888,1890)$, in which 1600 species from British India were described. Hooker (1895) also provided extensive descriptions along with illustrations of 100 orchids. After the establishment of the Botanical Survey of India (BSI) in 1890 at the Royal Botanic Garden, Calcutta (now Acharya Jagadish Chandra Bose Indian Botanic Garden), the Director, Sir George King, launched large scale studies on the Indian flora including orchids. These studies resulted in compilation of several regional floras (Duthie, 1903; Prain, 1903; Cooke, 1906; Haines, 1924; Gamble, 1928), where information on Orchidaceae has been detailed extensively. King and Pantling (1898), inspired by Hooker's work, published an illustrated account on the orchids of Sikkim Himalaya. Collett (1902) described 38 species in 18 genera from Shimla and its neighbouring regions. Duthie (1906) listed 45 genera and 173 species including a few illustrations. Gammie (1905a,b, 1906a,b, 1907a,b,c, 1908a,b,
1909, 1910, 1911, 1912) published a series of papers on orchids of the Bombay Presidency, which included 61 species in 30 genera. Cooke (1906) described 31 genera and 75 species of orchids from the same region. Subsequently, Blatter and McCann (1931a,b,c, 1932) revised the orchid flora of the Bombay Presidency and documented 132 species in 37 genera and described several new species. Brühl (1926) described 461 species belonging to 92 genera from Sikkim and surrounding areas.

By the post-independence period, fieldorchidology had become well-established in India. The era represented a phase where new reports of orchids from various regions started coming in. This is primarily due to the variety of ecological habitats and climatic conditions prevalent in the Western Himalayas, Eastern Himalayas and Western Ghats, where orchids are considered to be endemic and represent an important component of the vegetation. Ghose (1953), Pradhan (1976, 1979), Bose and Bhattacharjee (1980) provided preliminary information on the taxonomy of orchids in India. In addition, several inventories were published by various workers (Jain \& Mehrotra, 1984; Karthikeyan et al., 1989; Kumar \& Manilal, 1994; Misra, 2007; Schuiteman et al., 2021). Many new species have been reported across varying habitats. Recently published work by Singh et al. (2019) enumerated 1256 species in 155 genera, and Misra (2019) listed 1484 species from India. Several revisionary studies on different genera were undertaken by various workers: Coelogyne Lindl. (Das \& Jain, 1980), Calanthe R.Br. and Cymbidium (Rathore, 1983), Oberonia Lindl. (Ansari \& Balakrishnan, 1990), Bulbophyllum Thouars (Augustine et al., 2001), Vanda Gaud. ex Pfitzer (Limansenla et al., 2002), Eria Schltr. (Agrawala, 2009), Goodyerinae (Bhattacharjee, 2010), Habenaria Willd. (Chowdhury, 2011), Cleisostoma Blume (Phukan, 2011), Dendrobium Sw. (Sabapathy, 2013), Apostasioidae (Chowdhery, 2014), Cymbidieae (Kumar, 2015), Habenariinae (Kush, 2015) and Lady's Slipper Orchids (Chowdhery, 2015). Checklists and field guides for different regions exist for Western Himalayas (Raizada et al., 
1981; Seidenfaden \& Arora, 1982; Deva \& Naithani 1986; Pangtey et al., 1991; Jalal et al., 2008; Chowdhery \& Agrawala, 2013; Vij et al., 2013; Jalal \& Jayanthi, 2015; Jalal et al., 2019), Northeast India (Tuyama, 1966, 1971; Hegde, 1984; Ghatak \& Devi, 1986; Kataki, 1986; Kataki \& Hynniewta, 1986; Rao, 1986, 2007, 2010; Singh et al., 1990; Shukla et al., 1998; Chowdhery, 1998, 2009; Hynniewta et al., 2000; Barua, 2001; Chauhan, 2001; Kumar, 2001; Kumar \& Kumar, 2005; Pradhan, 2005; Lucksom, 2007; Deb \& Imchen, 2008; Sharma et al., 2013b; Verma et al., 2013; Rao \& Singh, 2015; Swami 2016, 2017; Bhattacharjee et al., 2018; Gogoi, 2018; Mao \& Deori, 2018; Rahamtulla et al., 2020), Peninsular India (Santapau \& Kapadia, 1966; Abraham \& Vatsala, 1981; Joseph, 1983; Kumar \& Sasidharan, 1986; Rao, 1998; Kumar \& Manilal, 2004; Misra, 2004, 2008, 2014; Kumar et al., 2007; Misra et al., 2008; Raju et al., 2008; Pande et al., 2010; Jalal \& Jayanthi, 2012; Narayanan et al., 2013; Barbhuiya \& Salunkhe, 2016; Jalal, 2018, 2019; Prasad et al., 2019; Venkaiah et al., 2020), and Andaman and Nicobar Islands (Shiva et al., 2003; Gupta et al., 2004; Pandey \& Diwakar, 2008; Karthigeyan et al., 2014). Around 10 new orchid names are introduced almost every year from the wild in India. Numerous new distributional records to the existing flora (national and regional) have been added. Although several new orchid species have been described from the subcontinent in recent years, many of them have turned out to be synonyms of previously existing species. To avoid such problems, putative new species need to be checked against the larger group globally, besides cross-checking for ecotypes and morphotypes (morphologically and genetically).

\section{In vitro studies}

Rao (1967) was the first to publish on the histogenesis and organogenesis of a few orchid seedlings in India. Subsequent tissue culture studies until the 1980s were rather preliminary and appeared infrequently (e.g., Chennaveeraiah \& Patil, 1973; Bapat \& Narayanaswami, 1977; Mathews \& Rao, 1980).
In vitro research on orchids in India have largely focused on horticulturally important genera (Mitra et al., 1976; Sharon \& Vasundhara, 1990; Katiyar et al., 1991; Kaushik \& Kishore, 1991, 1995; Seeni \& Latha, 1992, 2000; Piyathi \& Murthy, 1995; George \& Ravishankar, 1997; Nayak et al., 1997, 1998; Kulkarni \& Surwase, 1998; Sharma 1998; Sheelavantmath et al., 2000; Talukdar, 2001; Saiprasad \& Polisetty, 2003; Bejoy et al., 2004; Piria et al., 2005; Pant et al., 2008; Chugh et al., 2009; Shadang et al., 2009; Guha \& Rao, 2010, 2012; Vyas et al., 2009; Chauhan et al., 2010, 2015; Pant \& Swar, 2011; Mahendran \& Bai, 2012; Sibin et al., 2014; Sibin \& Gangaprasad, 2016; Arora et al., 2016; Lekshmi \& Decruse, 2018; Gurudeva, 2019; Madhavi \& Shankar, 2019).

Vij and coworkers established protocols for orchid tissue culture in India and carried out extensive research on genera of horticultural and folk values viz., Aerides Lour., Bulbophyllum, Cattleya Lindl., Coelogyne, Cymbidium, Dactylorhiza Neck. ex Nevski, Dendrobium, Eulophia R.Br. Goodyera R.Br., Luisia Gaud., Oncidium Sw., Paplionanthe Schltr., Phaius Lour., Rhynchostylis, Satyrium Sw., Vanda (Vij et al., 1984, 1986, 1987, 1989, 1994, 1995, 1997, 2000; Vij \& Pathak, 1988, 1989, 1990; Sharma et al., 1991; Vij \& Kaur, 1992; Vij, 1993; Kaur \& Vij, 1995, 2000; Vij \& Aggarwal, 2003; Aggarwal et al., 2008; Pathak et al., 2011, 2017; Anuprabha \& Pathak, 2012, 2019; Vasundhara et al., 2019). The National Research Centre (NRC) in Sikkim, which was established in 1996, has developed hybrid varieties in vitro of several orchid genera of ornamental value (eg., between Cattleya, Cymbidium, Dendrobium, Phaius) to encourage local farmers to enter the horticultural trade (Nagaraju \& Parthasarathy, 1994; Nagaraju \& Upadhayaya, 2001; Nagaraju et al., 2002, 2003, 2004). Standardized in vitro protocols to raise orchid species have also been established for many taxa from Northeast India, viz., Agrostophyllum Blume, Cleisostoma, Coelogyne, Cymbidium, Dendrobium, Eulophia, Paphiopedilum Pfitzer, Renanthera Lour., Vanda (Devi et al., 1990, 1997, 1998, 2006; Kumaria et al., 1990; Sharma \& Tandon, 1990; Hazarika \& 
Sarma, 1995; Datta et al., 1999; Devi \& Deka, 2000; Kumaria \& Tandon, 2000; Sinha et al., 2001; Jamir et al., 2002; Roy \& Bannerjee, 2003; Sinha \& Roy, 2004; Temjensangba \& Deb, 2005; Das et al., 2007; Deb \& Temjensangba, 2007; Shadang et al., 2007; Ng \& Saleh, 2011; Dohling et al., 2012; Paul et al., 2012; Mao \& Ranyaphi, 2013; Borah et al., 2015).

\section{Cytology and molecular biology}

Diversification and speciation in plants is often correlated with chromosome and genome evolution (Alix et al., 2017). Advancement in microscopy and molecular techniques has led to exhaustive cytogenetic research on orchids in India. Initial efforts focused on karyotyping epiphytic orchids to establish variations in this regard (Mehra \& Pal, 1961; Mehra \& Bawa, 1970; Mehra \& Vij, 1972; Kashyap \& Mehra, 1983; Mehra \& Kashyap, 1983a,b, 1986). The origin of some orchids in nature was attributed to aneuploidy rather than true polyploidy (Sharma \& Chatterji, 1961); however, this hypothesis has been tested on only very few taxa. Latha (2002) developed a staining method for rapid and convenient chromosome preparation from root tips of Orchidaceae members based on lactopropionic orcein. Besides, karyomorphological studies on several species of Cymbidium have been done in recent years (Sharma et al., 2010, 2012b; Rao et al., 2013).

The previous two decades have seen a rise in molecular and genomic studies on orchids around the world. In India, researchers have begun to employ these methods, and molecular biological tools and procedures are being used to understand the basis of orchid diversity and variation. The research has broadly focused on two topics: (i) barcoding as a tool for molecular taxonomy, and (ii) assessment of diversity through molecular markers. The Department of Botany at the University of Delhi has pioneered DNA barcoding of orchids in India, focusing on several medicinal and threatened species. Research has ranged from checking the applicability of the recommended locus/loci for congeneric species (Parveen et al.,
2012; Singh et al., 2012; Khasim \& Ramadu, 2018) to diverse orchid taxa (Parveen et al., 2017; Kishor \& Sharma, 2018). Several genetic barcoding markers such as ITS, matK, $r b c \mathrm{~L}$, and $r p o \mathrm{~B}$ and rpoC1, amplified fragment length polymorphism (AFLPs), double-digested random amplified DNA (ddRAD), inter simple sequence repeat (ISSRs), random amplification of polymorphic DNA (RAPDs, single primer amplification reactions (SPAR), simple sequence repeats (SSRs) in various taxon-specific combinations aided in assessing genetic diversity in nature (Sreedhar et al., 2007; Sharma et al., 2011, 2012a, 2013a; Chattopadhyay et al., 2012; Bhattacharyya et al., 2013, 2017; Manners et al., 2013; Thakur \& Kaur, 2013; Bhattacharyya \& Kumaria, 2015; Ramesh et al., 2016; Roy et al., 2017; Rao, 2020). Isolated studies have also been carried out on chloroplast genome sequencing and annotation (Biswal et al., 2017; Konhar et al., 2019) and transcription modulation in selected taxa (Nag \& Kumaria, 2018).

\section{Functional biology and ecology}

It is widely accepted that above (pollination) and below (fungal endophytes) ground mutualisms have shaped the diversity and occurrence of orchids, and there is a co-evolutionary relationship between the mutualistic partners (Waterman et al., 2011; Selosse, 2014). Distribution patterns of orchids in various ecological regions are more random than regular. The gaps need to be validated through functional and evolutionary ecological studies, which at present have been inadequate in India. Studies on the reproductive ecology of the Indian orchids are scant, with only few isolated species having been superficially studied (Chaturvedi, 2009a,b; Chaturvedi \& Chaturvedi, 2010, 2011; Attri \& Kant, 2011; Buragohain et al., 2015; Buragohain \& Chaturvedi, 2020; Dangat \& Gurav, 2020).

Orchid mycorrhizal studies in India have largely focused on molecular characterization of endophytic fungi (Senthilkumar \& Krishnamurthy, 1998; Senthilkumar, 2003; Saha \& Rao, 2006; Aggarwal et al., 2012; Behera et al., 2013; 
Mahendran et al., 2013; Sathiyadash et al., 2013, 2014; Rajulu et al., 2016; Srivastava et al., 2018), besides a single study involving nitrogen metabolizing enzymes (Hajong et al., 2013). Future research should focus on community structure, population biology and other related ecological parameters to assess their implication on orchid fecundity and survival.

It is imperative to gather information on functional ecology of species in situ to boost conservation efforts. The declining populations of pollinators due to climate change and loss of habitat have amplified the threat to the survival of orchids, that often depend on specialized pollinators for reproductive success (Abrol, 2012). These aspects are important as they help in understanding the distribution pattern of orchids in various ecosystems, and elucidate the role of mutualistic partners in the reproductive success, and structure and diversity in natural plant communities.

\section{Indian Orchidology: prospects and conservation}

Restrictions imposed on the commercial collection of orchids for medicinal and horticultural purposes have resulted in their illegal gathering from natural habitats. Although work on micropropagation using various explants in India is substantial, most of these studies have limited utility. The plants raised by tissue culture in most cases have not been reintroduced to nature because of logistics and requiring a multidisciplinary approach. Folk medicine is one of the major contributors to loss of viable orchid populations through overharvesting. Although an abundance of literature on ethnobotany is available on Indian orchids, preparations from orchid taxa need to be scientifically evaluated for effectiveness. Capacity building through skill enhancement in orchid biology, micropropagation, and nursery cultivation is imperative to boost conservation efforts. Most importantly, critical knowledge of reproductive strategies of most threatened orchids is insufficient. Information on threats, habitat ecology, and population dynamics is also unavailable for the majority of the species. Accordingly, the development of conservation policies is difficult. If pertinent measures are not taken for the protection of orchids, many of them may soon become extinct in nature. For example, Spathoglottis arunachalensis Tsering \& Prasad, a recently described orchid (Tsering \& Prasad, 2020) is not seen any more in the wild, as anthropogenic activities have disturbed its habitat. Many such examples are reminders that ex situ and in situ conservation measures are a necessity to preserve these plants. The National Orchidarium housed in Shillong (Meghalaya), the Sessa Orchid Sanctuary in Tipi (Arunachal Pradesh), and the Jawaharlal Nehru Tropical Botanical Garden and Research Institute, Trivandrum (Kerala) have become the largest repositories of live orchids in India, and need to be developed as a focal point for the accumulation of a live gene bank of Indian orchids. In lieu of sustainable research, it is imperative that collection and accession of live specimens be promoted instead of herbarium or fixed specimens which are destructive in nature, at least in cases of threatened species. Botanical gardens, orchidaria and sanctuaries can provide accession numbers for such live collections to researchers. This will not only promote research on numerous fundamental aspects, but also can help in the maintenance of a gene pool, to act as a bank for micropropagation, and to serve as reliable repositories for re-introducing species that have disappeared from wild.

Despite having large number of herbarium specimens in various regional institutions/ herbaria, very few have been/ are being digitized in India. Besides, physical access to these specimens is also marred by red tape. To maintain academic and research growth, institutions with rich herbaria should make provisions for loaning/ exchange of specimens, both within and outside the country. It is crucial to understand that conservation of biodiversity can be facilitated through access of genetic resources and collaboration in research. 


\section{Conclusions}

Research on orchids in general has taken major leaps in the last few years in India. Orchids are being used as model systems to study flowering pattern, developmental biology, and morphogenesis worldwide. Indian orchidologists have described several new species and the first reports of their presence in many regions through continued explorations. Ex situ conservation of orchids through in vitro methods as well as threat assessment and in situ conservation of threatened species is being carried out. Although molecular techniques are being used for resolving species complexes and constructing evolutionary relationships, the research is still in a nascent stage. Conservation genetics is another thrust area, which has been missing in current orchidological studies in the country. It is important to understand the geneflow and interconnectivity between populations to design strategies for conservation and species recovery. Science in India is traditionally an individualistic endeavour and thus hampered by isolated and unequal growth in knowledge; in spite of sincere efforts by many, larger objectives remain distant. This uncoordinated approach is also evident in conservation. Despite advances in orchid studies in India, research is lagging in the conversion of knowledge into applied conservation. It is imperative to design novel approaches of in situ regeneration and restoration of habitats, which could support sizeable populations.

\section{Acknowledgements}

Financial support from the Institution of Eminence, University of Delhi (IoE/FRP/LS/ 2020/27) is gratefully acknowledged. AA is thankful to the Council of Scientific and Industrial Research for the award of a Senior Research Fellowship. The authors are grateful to the reviewers for making relevant suggestions, and improve the manuscript.

\section{Literature Cited}

ABRAHAM A. \& P. VATSALA 1981. Introduction to Orchids. Tropical Botanic Garden and Research Institute, Trivandrum.

ABROL D.P. 2012. Climate change and pollinators. In: ABROL D.P. (ed.), Pollination Biology. Springer, Dordrecht. pp. 479-508. https://doi.org/10.1007/97894-007-1942-2_15

ADIT A., KOUL M. \& R. TANDON 2020. Twelve new additions in the orchid flora of Tripura, north-east India. Check List 16: 17-25. https://doi.org/10.15560/16.1.17

AGGARWAL S., PATHAK P. \& S.P. VIJ 2008. Asymbiotic seed germination and seedling development in an endangered and commercially important orchid-Vanda coerulea. Plant Cell Biotechnology and Molecular Biology 9: $25-30$.

AGGARWAL S.C., BERI N.S., RASTOGI S. \& A. ADHOLEYA 2012. In vitro symbiotic seed germination and molecular characterization of associated endophytic fungi in a commercially important and endangered Indian orchid Vanda coerulea Griff. ex. Lindl. European Journal of Environmental Sciences 2: 33-42. https:// doi.org/10.14712/23361964.2015.36

AGRAWALA D.K. 2009. Taxonomic studies on the genus Eria Lindl. (Orchidaceae) in India. Ph.D. Thesis (unpublished), Kalyani University, West Bengal.

ALIX K., GERARD P.R, SCHWARZACHER T. \& J.S. HESLOP-HARRISON 2017. Polyploidy and interspecific hybridization: partners for adaptation, speciation and evolution in plants. Annals of Botany 120 : 183-194. https://doi.org/10.1093/aob/mcx079

ANSARI R. \& N.P. BALAKRISHNAN 1990. A revision of the Indian species of Oberonia (Orchidaceae). Orchid Monographs 4: 1-82.

ANUPRABHA \& P. PATHAK 2012. Green pod culture in Dendrobium chrysanthum Lindl.: a study in vitro. The Journal of the Orchid Society of India 26: 105-109.

ANUPRABHA \& P. PATHAK 2019. Asymbiotic seed germination and seedling development in Coelogyne fimbriata Lindl. The Journal of the Orchid Society of India 33: 83-90.

ARORA S.K., PATHAK P., VERMA S., PRAKASH P., DHIMAN K. \& K.C. MAHANT 2016. Mass propagation of Dendrobium amoenum Wall. ex Lindl. through stem nodal explants: a study in vitro. The Journal of the Orchid Society of India 30: 51-56.

ATTRI L.K. \& R. KANT 2011. Orchid pollination: an observation on pollination-pollinator interaction in Cymbidium pendulum (Sw.) Roxb. Current Botany 2(7): $1-7$. 
AUGUSTINE J., KUMAR Y. \& J. SHARMA 2001. Orchids of India II: biodiversity and status of Bulbophyllum Thou. Daya Publication House, Delhi.

BAPAT V.A. \& S. NARAYANASWAMI 1977. Rhizogenesis in tissue culture of the orchid Spathoglottis. Bulletin of the Torrey Botanical Club 104: 2-4. https:// doi.org/10.2307/2484656

BARBHUIYA H. \& C.K. SALUNKHE 2016. Orchids of Maharashtra, India: a review. Richardiana 16: 111-140.

BARUA I.C. 2001. Orchid flora of Kamrup district, Assam (with illustrations). Bishen Singh \& Mahendra Pal Singh, Dehradun.

BEHERA D., RATH C.C. \& U. MOHAPATRA 2013. Medicinal orchids in India and their conservation: a review. Floriculture and Ornamental Biotechnology 7: 53-59.

BEJOY M., KUMAR C.S., RADHIK B.J. \& J. JACOB 2004. Asymbiotic seed germination and early seedling development of the dove orchid Peristeria elata Hook. The Journal of the Orchid Society of India 18: 75-79.

BHATTACHARJEE A. 2010. Taxonomic studies on the subtribe Goodyerinae Klotzsch (Orchidaceae) in India. Ph.D. Thesis (unpublished), Vidyasagar University, Midnapore, West Bengal.

BHATTACHARJEE B., DUTTA B.K. \& P.K. HAJRA 2018. Orchid flora of southern Assam (Barak Valley): diversity and conservation. Bishen Singh Mahendra Pal Singh, Dehradun.

BHATTACHARYYA P. \& S. KUMARIA 2015. Molecular characterization of Dendrobium nobile Lindl., an endangered medicinal orchid, based on randomly amplified polymorphic DNA. Plant Systematics and Evolution 301: 201-210. https://doi.org/10.1007/s00606014-1065-1

BHATTACHARYYA P., KUMARIA S., KUMAR S. \& P. TANDON 2013. Start Codon Targeted (SCoT) marker reveals genetic diversity of Dendrobium nobile Lindl., an endangered medicinal orchid species. Gene 529: 21-26. https://doi.org/10.1016/j.gene.2013.07.096

BHATTACHARYYA P., GHOSH S., MANDI S.S., KUMARIA S. \& P. TANDON 2017. Genetic variability and association of AFLP markers with some important biochemical traits in Dendrobium thyrsiflorum, a threatened medicinal orchid. South African Journal of Botany 109: 214-222. https://doi.org/10.1016/ j.sajb.2016.12.012

BISWAL D., KONHAR R., DEBNATH M., PARAMESWARAN S., SUNDAR D. \& P. TANDON 2017. Chloroplast genome sequence annotation of Dendrobium nobile (Asparagales: Orchidaceae), an endangered medicinal orchid from Northeast India.
PLoS Currents 9: 1-10. https://doi.org/10.1371/ currents.tol.cf1709613759c2223eb582c0fa694cc7

BLATTER E. \& C. MCCANN 1931a. Revision of the flora of the Bombay Presidency-Orchidaceae (Part 16). The Journal of the Bombay Natural History Society 35: 254-275.

BLATTER E. \& C. MCCANN 1931b. Revision of the flora of the Bombay Presidency-Orchidaceae (Part 17). The Journal of the Bombay Natural History Society 35: 484-495.

BLATTER E. \& C. MCCANN 1931c. Revision of the flora of the Bombay Presidency-Orchidaceae (Part 18). The Journal of the Bombay Natural History Society 35: $722-736$.

BLATTER E. \& C. MCCANN 1932. Revision of the flora of the Bombay Presidency - Orchidaceae (Part 19). The Journal of the Bombay Natural History Society 36: 13-28.

BORAH N.J., CHAKRABORTY S., CHOUDHARY S.R. \& B.K. DUTTA 2015. In vitro propagation of Paphiopedilum spicerianum (Reichb. F.) Pfitz. - a rare and endangered orchid species from North East India. The Journal of the Orchid Society of India 29: 85-90.

BOSE T.K. \& S.K. BHATTACHARJEE 1980. Orchids of India. Naya Prokash, Kolkata.

BRÜHL P. 1926. A guide to the orchids of Sikkim. Thacker, Spink and Co., Shimla.

BURAGOHAIN B. \& S.K. CHATURVEDI 2020. Thoraxinotribic pollination in an endangered orchid Thunia alba (Lindl.) Rchb.f. of North-East India. The International Journal of Plant Reproductive Biology 12(2): 149-152.

BURAGOHAIN B., CHATURVEDI S.K. \& N. PURO 2015. Biotic pollination in Rhynchostylis retusa (L.) Bl. (Orchidaceae). The International Journal of Plant Reproductive Biology 7(1): 78-83.

CARAKA, SHASHIREKHA H.K. \& B.S. SUKUMAR. 2017. Charaka Samhita, Chaukhamba Publications, New Delhi.

CHATTOPADHYAY P., BANERJEE N. \& B. CHAUDHARY 2012. Genetic characterization of selected medicinal Dendrobium (Orchidaceae) species using molecular markers. Research Journal in Biology 2: 117-125.

CHATURVEDI S.K. 2009a. Mechanism of self-pollination in Cymbidium sinense (Jacks. ex Ander). Willd. (Orchidaceae). The International Journal of Plant Reproductive Biology 1(1): 1-4.

CHATURVEDI S.K. 2009b. Mechanism of pollination in Coelogyne corymbosa Lindl. (Orchidaceae). The International Journal of Plant Reproductive Biology 1(2): 133-135. 
CHATURVEDI S.K \& S. CHATURVEDI 2010. Biotic pollination in Aerides odorata Lour. (Orchidaceae). The International Journal of Plant Reproductive Biology 2(1): 45-49.

CHATURVEDI S.K \& S. CHATURVEDI 2011. A unique mode of autogamy in Flickingeria calocephala Tsi \& Chen (Orchidaceae). The International Journal of Plant Reproductive Biology 3(1): 1-10.

CHAUHAN A.S. 2001. A conspectus of orchids of Manipur: their status and conservation. In: PATHAK, P., SEHGAL R.N., SHEKHAR N., SHARMA M. \& A. SOOD (eds.), Orchids: Science and Commerce. Bishen Singh Mahendra Pal Singh, Dehradun. pp. 81-99.

CHAUHAN S., PATHAK P., ANUPRABHA \& S. SHARMA 2015. Regeneration of Eulophia dabia through rhizome explants and flowering: a study in vitro. The Journal of the Orchid Society of India 29: 61-66.

CHAUHAN S., PATHAK P., SHARMA S. \& S.P. VIJ 2010. In vitro asymbiotic seed germination of Satyrium nepalense, an endangered medicinally important orchid. The Journal of the Orchid Society of India 24: 61-66.

CHENNAVEERAIAH M.S. \& S.J. PATIL 1973. In vitro morphogenesis in seed cultures of an orchid Spathoglottis plicata. Proceedings of the Indian Science Congress 60: 410-411.

CHOWDHERY H.J. 1998. Orchid flora of Arunachal Pradesh. Bishen Singh Mahendra Pal Singh, Dehradun.

CHOWDHERY H.J. 2009. Orchid diversity in Northeastern states of India. The Journal of the Orchid Society of India 23: 19-42.

CHOWDHERY H.J. 2014. Studies on the subfamily Apostasioideae (Orchidaceae) in India. Nelumbo 55: $1-13$.

CHOWDHERY H.J. 2015. Lady's slipper orchids of India. Bishen Singh Mahendra Pal Singh, Dehradun.

CHOWDHERY H.J. \& D.K. AGRAWALA 2013. A century of West Himalayan orchids. Bishen Singh Mahendra Pal Singh, Dehradun.

CHOWLU K., RAO A.N., ANGELA N. \& S.P. VIJ 2013. A brief account of the genus Bulbophyllum (Orchidaceae) in Manipur, India. Rheedea 23(2): 86-97.

CHOWDHURY S. 2011. Revision of genus Habenaria (Orchidaceae) in India. Ph.D. Thesis (unpublished), Kalyani University, West Bengal.

CHRISTENHUSZ M.J. \& J.W. BYNG 2016. The number of known plants species in the world and its annual increase. Phytotaxa 261: 201-217. https://doi.org/ 10.11646/phytotaxa.261.3.1

CHUGH S., GUHA S. \& U.I. RAO 2009. Micropropagation of orchids: a review on the potential of different explants. Scientia Horticulturae 122: 507-520. https://doi.org/10.1016/j.scienta.2009.07.016

COLLETT H. 1902. Flora Simlensis. Thacker, Spink and Co., Shimla.

COOKE T. 1906. Flora of Presidency of Bombay. Volume 2. Botanical Survey of India, Kolkata.

DANGAT B.T. \& R.V. GURAV 2020. Pollination studies in the genus Habenaria Willd. (Orchidaceae) from Western Ghats, India. In: KHASIM S.M., HEGDE S.N., GONZÁLEZ-ARNAO M.T. \& K. THAMMASIRI (eds.), Orchid Biology: Recent Trends \& Challenges. Springer, Singapore. pp. 401-421. https://doi.org/ 10.1007/978-981-32-9456-1_20

DAS M.C., KUMARIA S. \& P. TANDON 2007. Protocorm regeneration, multiple shoot induction and ex vitro establishment of Cymbidium devonianum Paxt. Asian Journal of Plant Sciences 6: 349-353.

DAS S. \& S.K. JAIN 1980. Orchidaceae: genus Coelogyne. Fascicles of Flora of India 5: 1-33.

DATTA K.B., KANJILAL B. \& D.D. SARKER 1999. Artificial seed technology: development of a protocol in Geodorum densiflorum (Lam.) Schltr. - An endangered orchid. Current Science 76: 167-72.

DEB C.R. \& TEMJENSANGBA 2007. Direct regeneration of shoot-buds Arachnis labrosa foliar explants. The Journal of the Orchid Society of India 21: 7-9.

DEB C.R. \& T. IMCHEN 2008. Orchid diversity of Nagaland. Scichem Publishing House, Udaipur.

DEVA S. \& H.B. NAITHANI 1986. The orchid flora of North-West Himalaya. Print and Media Associates, New Delhi.

DEVI J. \& P.C. DEKA 2000. Induction of polyploidy in Phaius tankervilliae. The Journal of the Orchid Society of India 14: 1-5.

DEVI J., BORTHAKUR B. \& P.C. DEKA 1997. Clonal propagation of Dendrobium moschatum and Cymbidium aloifolium through shoot-tip culture. The Journal of the Orchid Society of India 11: 19-21.

DEVI J., NATH M., DEVI M. \& P.C. DEKA 1990. Effect of different media on germination and growth of some north-east Indian species of Dendrobium. The Journal of the Orchid Society of India 4: 45-49.

DEVI J., RAY B.K., CHETIA S. \& P.C. DEKA 1998. Regeneration of low temperature stored encapsulated protocorms of orchids. The Journal of the Orchid Society of India 12: 39-41.

DEVI C.G., M. DAMAYANTI \& G.J. SHARMA 2006. In vitro culture of Vanda amesiana Reichb. F. The Journal of the Orchid Society of India 20: 7-10. 
DOHLING S., KUMARIA S. \& P. TANDON 2012. Multiple shoot induction from axillary bud cultures of the medicinal orchid. AoB Plants 2012: 1-7. https:// doi.org/10.1093/aobpla/pls032

DUTHIE J.F. 1903. Flora of the Upper Gangetic plain and of the adjacent Siwalik and Sub-Himalayan Tracts. Volume 1. Superintendent of Government Printing, Kolkata.

DUTHIE J.F. 1906. The orchids of the north-western Himalaya. Annals of the Royal Botanical Garden, Kolkata 9: 81-211.

EDENS-MEIER R. \& P. BERNHARDT 2014. Darwin's orchids: then and now. University of Chicago Press, Chicago.

GAMBLE J.S. 1928. The Flora of the Presidency Madras. Volume 3. London.

GAMMIE G.A. 1905a. The orchids of the Bombay Presidency. The Journal of the Bombay Natural History Society 16: 429-433.

GAMMIE G.A. 1905b. The orchids of the Bombay Presidency. The Journal of the Bombay Natural History Society 16: 562-569.

GAMMIE G.A. 1906a. The orchids of the Bombay Presidency. The Journal of the Bombay Natural History Society 17: 31-37.

GAMMIE G.A. 1906b. The orchids of the Bombay Presidency. The Journal of the Bombay Natural History Society 17: 940-942.

GAMMIE G.A. 1907a. The orchids of the Bombay Presidency. The Journal of the Bombay Natural History Society 18: 88-91.

GAMMIE G.A. 1907b. The orchids of the Bombay Presidency. The Journal of the Bombay Natural History Society 18: 586-590.

GAMMIE G.A. 1907c. The orchids of the Bombay Presidency. The Journal of the Bombay Natural History Society 18: 833-834.

GAMMIE G.A. 1908a. The orchids of the Bombay Presidency. The Journal of the Bombay Natural History Society 19: 139-141.

GAMMIE G.A. 1908b. The orchids of the Bombay Presidency. The Journal of the Bombay Natural History Society 19: 624-626.

GAMMIE G.A. 1909. The orchids of the Bombay Presidency. The Journal of the Bombay Natural History Society 20: 126-129.

GAMMIE G.A. 1910. The orchids of the Bombay Presidency. The Journal of the Bombay Natural History Society 20: 597-602.

GAMMIE G.A. 1911. The orchids of the Bombay Presidency. The Journal of the Bombay Natural History Society 21: 171-174.
GAMMIE G.A. 1912. The orchids of the Bombay Presidency. The Journal of the Bombay Natural History Society 21: 1129-1130.

GENTRY A.H. \& C. DODSON 1987. Contribution of nontrees to species richness of a tropical rain forest. Biotropica 19: 149-156. https://doi.org/10.2307/2388737

GEORGE P.S. \& A. RAVISHANKAR 1997. In vitro multiplication of Vanilla planifolia using axillary bud explant. Plant Cell Reports 16: 490-494. https://doi.org/ 10.1007/BF01092772

GHATAK J. \& R.K.J. DEVI 1986. Orchids of Manipur. In: VIJ S.P. (ed.), Biology, conservation, and culture of orchids. Affiliated East West Press, New Delhi. pp. 357-362.

GHOSE B.N. 1953. Beautiful Indian orchids and how to grow them. Ghose and Co., Darjeeling.

GOGOI K. 2018. Wild orchids of Assam-a pictorial guide. Assam State Biodiversity Board, Guwahati.

GRIFFITH W. 1851. Notulae ad plantas asiaticas. Volume 3. Kolkata.

GUHA S. \& I.U. RAO 2010. Culture surface and exogenous putrescine-altered shoot growth pattern in mannitoland cadmium chloride-pretreated callus of Cymbidium via del Playa "Yvonne". In Vitro Cellular \& Developmental Biology-Plant 46: 491-498. https://doi.org/10.1007/ s11627-010-9322-7

GUHA S. \& I.U. RAO 2012. Nitric oxide promoted rhizome induction in Cymbidium shoot buds under magnesium deficiency. Biologia Plantarum 56: 227-236. https:// doi.org/10.1007/s10535-012-0081-7

GUPTA S., PORWAL M.C. \& P.S. ROY 2004. Orchid diversity of Great Nicobar Biosphere Reserve. Current Science 86(10): 1372-1374.

GURUDEVA M.R. 2019. In vitro seed germination and developmental morphology of seedlings in Dendrobium ovatum (L.) Kraenzl. The Journal of the Orchid Society of India 33: 31-42.

HAINES H.H. 1924. The Botany of Bihar and Orissa. Adlard, London.

HAJONG S., KUMARIA S. \& P. TANDON 2013. Comparative study of key phosphorus and nitrogen metabolizing enzymes in mycorrhizal and nonmycorrhizal plants of Dendrobium chrysanthum Wall. ex Lindl. Acta Physiologiae Plantarum 35: 2311-2322. https:/ /doi.org/10.1007/s11738-013-1268-z

HAZARIKA R.B. \& M. SARMA 1995. In vitro germination and regeneration of Dendrobiium transparens Lindl. The Journal of the Orchid Society of India 9: 51-54.

HEGDE S.N. 1984. Orchids of Arunachal Pradesh. Forest Dept., Itanagar.

HOOKER J.D. 1888. The Flora of British India. Volume 5. Reeve and Co., Kent. 
HOOKER J.D. 1890. The Flora of British India 6. Reeve and Co., Ashford, Kent.

HOOKER J.D. 1895. A century of Indian orchids. Annals of Royal Botanical Garden, Kolkata 5: 1-189.

HYNNIEWTA T.M., KATAKI S.K. \& B.M. WADHWA 2000. Orchids of Nagaland. Botanical Survey of India, Kolkata.

JAIN S.K. \& A. MEHROTRA 1984. A Preliminary inventory of Orchidaceae in India. Botanical Survey of India, Kolkata.

JALAL J.S. 2012. Status, threats and conservation strategies for orchids of western Himalaya, India. Journal of Threatened Taxa 4: 3401-3409. https://doi.org/10.11609/ JoTT.o3062.3401-9

JALAL J.S. 2018. Orchids of Maharashtra. Botanical Survey of India, Kolkata.

JALAL J.S. 2019. Diversity and distribution of orchids of Goa, Western Ghats, India. Journal of Threatened Taxa 11: 15015-15042. https://doi.org/10.11609/ jott.4499.11.15.15015-15042

JALAL J.S. \& J. JAYANTHI 2012. Endemic orchids of peninsular India: A review. Journal of Threatened Taxa 4: 3415-3425. https://doi.org/10.11609/ JoTT.o3091.3415-25

JALAL J.S. \& J. JAYANTHI 2015. An annotated checklist of the orchids of Western Himalaya, India. Lankesteriana 15: 7-50.

JALAL J.S, KUMAR P., RAWAT G.S. \& Y.P.S. PANGTEY 2008. Orchidaceae, Uttrakhand, Western Himalaya, India. Check List 4: 304-320. https://doi.org/ 10.15560/4.3.304

JALAL J.S., SUYAL R. \& L.M. TEWARI 2019. Orchids of Nainital, Western Himalaya. Indu Book Services Pvt. Ltd., New Delhi.

JAMIR C., DEVI J. \& P.C. DEKA 2002. In vitro propagation of Cymbidium iridioides and C. lowianum. The Journal of the Orchid Society of India 16: 83-89.

JOSEPH J. 1983. Orchids of Nilgiris. Botanical Survey of India, Kolkata.

KARTHIGEYAN K., JAYANTHI J., SUMATHI R. \& J.S. JALAL 2014. A review of the orchid diversity of Andaman \& Nicobar Islands, India. Richardiana 15: $9-85$.

KARTHIKEYAN S., JAIN S.K., NAYAR M.P. \& M. SANJAPPA 1989. Florae Indicae Enumeratio: Monocotyledonae. Botanical Survey of India, Kolkata.

KASHYAP S.K. \& P.N. MEHRA 1983. Cytological investigations on West-Himalayan orchids Tribe: Orchideae. II. Several genera. Cytologia, 48(3): 647-657. https://doi.org/10.1508/cytologia.48.647
KATAKI S.K. 1986. Orchids of Meghalaya. Meghalaya Forest Department, Shillong.

KATAKI S.K \& T.M. HYNNIEWTA 1986. Orchids of Nagaland. In: VIJ S.P. (ed.), Biology, conservation, and culture of orchids. Affiliated East West Press, New Delhi. pp. 351-356.

KATIYAR R.S., SHARMA G.D. \& R.R. MISHRA 1991. Fungal endophyte and the growth of Cymbidium giganteum Wall. seedlings under different light regimes. The Journal of the Orchid Society of India 5: 9-15.

KAUR P. \& S.P. VIJ 1995. Morphogenetic response of Rhynchostylis retusa Bl. inflorescence segments: a study in vitro. The Journal of the Orchid Society of India 9: 85-90.

KAUR S. \& S.P. VIJ 2000. Regeneration potential of Saccolabium papillosum leaf segments. The Journal of the Orchid Society of India 14: 67-73.

KAUSHIK P. \& N. KISHORE 1991. Antibacterial potential of Pholidota articulata Lindl. - a study in vitro. The Journal of the Orchid Society of India 5: 93-96.

KAUSHIK P. \& N. KISHORE 1995. Antibacterial activity of Dendrobium amoenum Wall. ex Lindl. - a study in vitro. The Journal of the Orchid Society of India 9: 33-35.

KHASIM S.M. \& J. RAMUDU 2018. Deoxyribonucleic acid barcoding of some Indian Coelogyninae (Orchidaceae). Proceedings of the National Academy of Sciences, India Section B: Biological Sciences 88: 277-284. https://doi.org/10.1007/s40011-016-0756-5

KING G. \& R. PANTLING 1898. The orchids of the Sikkim Himalaya. Royal Botanic Garden, Calcutta.

KISHOR R. \& G.J. SHARMA 2018. The use of the hypervariable $\mathrm{P} 8$ region of $\operatorname{trnL}$ (UAA) intron for identification of orchid species: evidence from restriction site polymorphism analysis. PloS one 13: 1-20. https:// doi.org/10.1371/journal.pone.0196680

KONHAR R., DEBNATH M., VISHWAKARMA S., BHATTACHARJEE A., SUNDAR D., TANDON P., DASH D. \& D.K. BISWAL 2019. The complete chloroplast genome of Dendrobium nobile, an endangered medicinal orchid from north-east India and its comparison with related Dendrobium species. PeerJ 7: 1-28. https://doi.org/10.7717/peerj.7756

KULKARNI A.R. \& B.S. SURWASE 1998. In vitro propagation of Aerides maculosum Lindl. The Journal of the Orchid Society of India 12: 47-51.

KUMAR C.S. 2001. Orchids of Sikkim - a historical perspective. In: PATHAK P., SEHGAL R.N., SEKHAR N., SHARMA M. \& A. SOOD (ed.). Orchids: Science and Commerce. Bishen Singh Mahendra Pal Singh, Dehra Dun. pp. 101-143. 
KUMAR C.S. \& K.S. MANILAL 1994. A catalogue of Indian orchids. Bishen Singh Mahendra Pal Singh, Dehradun.

KUMAR C.S. \& K.S MANILAL 2004. Orchids of Kerala. In: KUMAR C.S. \& K.S. MANILAL (eds.), Orchid memories; a tribute to Gunnar Seidenfaden. Mantor and IAAT, India. pp. 197-198.

KUMAR C.S. \& P.C.S. KUMAR 2005. An orchid digest of Manipur, Northeast India. Rheedea 15:1-70.

KUMAR M. \& N. SASIDHARAN. 1986. Orchids of Kerala and their conservation. In: Vij S.P. (ed.), Biology, conservation, and culture of orchids. Affiliated East West Press, New Delhi. pp. 363-376.

KUMAR P., JALAL J.S. \& G.S. RA. 2007. Orchidaceae, Chotanagpur, state of Jharkhand. Check List 3: 297-304. https://doi.org/10.15560/3.4.297

KUMAR V. 2015. Taxonomic studies on the tribe Cymbidieae Pfitz. (Orchidaceae) in India. Ph.D. Thesis (unpublished), Kumaun University, Nainital.

KUMARIA S. \& P. TANDON 2000. Effect of growth regulators on peroxidase, polyphenol oxidase, and IAAoxidase activities and phenolic content during protocorm development of Dendrobium fimbriatum var. oculatum. The Journal of the Orchid Society of India 14: 27-39.

KUMARIA S., CHRUNGOO N.K. \& P. TANDON 1990. Activities of some oxidative enzymes in axenic cultures of protocorms of Cymbidium giganteum Wall. as influenced by different growth regulators. The Journal of the Orchid Society of India 4: 37-44.

KUSH L. 2015. Taxonomic revision of subtribe Habenariinae Benth. (Orchidaceae) in India. Ph.D. Thesis (unpublished), Kumaun University, Nainital.

LATHA P.G. 2002. Lactopropionic orcein as a suitable stain for mitotic chromosomes of Orchidaceae. Journal of Phytological Research 15: 25-27.

LEKSHMI S. \& S.W. DECRUSE 2018. In vitro symbiotic seed germination of Vanda spathulata (L.) Spreng., a vulnerable orchid of Western Ghats. The Journal of the Orchid Society of India 32: 113-119.

LIMANSENLA, KUMAR Y. \& J. SHARMA 2002. Orchids of India III. Biodiversity and status of Vanda Jones ex R.Br. Daya Publishing House, Delhi.

LINNAEUS C. 1753. Species Plantarum. Laurentius Salvius, Stockholm.

LUCKSOM S.Z. 2007. The orchids of Sikkim and North East Himalaya. S.Z. Lucksom, Siliguri.

MADHAVI M.A \& P.C. SHANKAR 2019. Effect of different growth additives on seed germination of $V$ anda tessellata (Roxb.) Hook. ex D.Don - a medicinal orchid. The Journal of the Orchid Society of India 33: 105-112.

MAHENDRAN G. \& V.N. BAI 2012. Direct somatic embryogenesis and plant regeneration from seed derived protocorm of Cymbidium bicolor Lindl. Scientia Horticulturae 135: 40-44. https://doi.org/10.1016/ j.scienta.2011.12.003

MAHENDRAN G., MUNIAPPAN V., ASHWINI M., MUTHUKUMAR T. \& V.N. BAI 2013. Asymbiotic seed germination of Cymbidium bicolor Lindl. (Orchidaceae) and the influence of mycorrhizal fungus on seedling development. Acta Physiologica Plantarum 35: 829-840. https://doi.org/10.1007/s11738-012-1127-3

MANNERS V., KUMARIA S. \& P. TANDON 2013. SPAR methods revealed high genetic diversity within populations and high gene flow of Vanda coerulea Griff. ex Lindl. (blue vanda), an endangered orchid species. Gene 519: 91-97. https://doi.org/10.1016/ j.gene.2013.01.037

MAO A.A. \& R.A. RANYAPHI 2013. Studies on in vitro asymbiotic germination of Paphiopedilum species of north east India. The Journal of the Orchid Society of India 27: 9-14.

MAO A.A. \& C. DEORI 2018. Checklist of orchids of Manipur-A pictorial handbook. Forest Department, Government of Manipur and Botanical Survey of India, Shillong.

MATHEWS V.H. \& P.S. RAO 1980. In vitro multiplication of $V$ anda hybrids through tissue culture technique. Plant Science Letters 17: 383-389. https://doi.org/10.1016/ 0304-4211(80)90171-6

MEDHI R.P., CHAKRABORTI M. \& RAMPAL 2012. Orchid biodiversity in India: Conservation and utilization. Indian Journal of Genetics and Plant Breeding 72: 148-156.

MEHRA P.N. \& K.S. BAWA 1970. Cytological observations on some Northwest Himalayan orchids. Caryologia 23: 273-282. https://doi.org/ 10.1080/00087114.1970.10796368

MEHRA P.N. \& S.K. KASHYAP 1983a. Cytological studies in some west Himalayan orchids. Tribe: Neottieae. I. Sub-tribe: Limodorinae. Caryologia 36: 33-45. https:// doi.org/10.1080/00087114.1983.10797642

MEHRA P.N. \& S.K. KASHYAP 1983b. Cytological studies in some west Himalayan orchids. Tribe: Neottieae. II. Sub-Tribe: Neottiinae. Caryologia 36: 47-55. https:// doi.org/10.1080/00087114.1983.10797643

MEHRA P.N. \& S.K. KASHYAP 1986. Cytological studies in some west Himalayan orchids. Tribe: Neottieae. III. Sub-Tribe: Spiranthinae. Caryologia 39: 151-160. https:/ /doi.org/10.1080/00087114.1986.10797776 
MEHRA P.N. \& S.P. VIJ 1972. Cytological studies in the East Himalayan Orchidaceae-1: Neottieae. Caryologia 25: 237-251. https://doi.org/10.1080/ 00087114.1972 .10796479

MEHRA P.N. \& Y. PAL 1961. Cytological observation on some Indian members of Orchidaceae. Proceedings of $48^{\text {th }}$ Indian Science Congress, Roorkee. pp. 294.

MISRA S. 2004. Orchids of Orissa. Bishen Singh Mahendra Pal Singh, Dehradun.

MISRA S. 2007. Orchids of India, a glimpse. Bishen Singh Mahendra Pal Singh, Dehradun.

MISRA S. 2008. Orchids of Eastern Ghats: a field guide for identification. Regional Plant Resource Centre, Bhubaneswar.

MISRA S. 2014. Orchids of Odisha: a handbook. Bishen Singh Mahendra Pal Singh, Dehradun.

MISRA S. 2019. Orchids of India - A handbook. Bishen Singh Mahendra Pal Singh, Dehradun.

MISRA S., PANDA S.P. \& D. SAHOO 2008. Orchid flora of Andhra Pradesh, India. Bulletin of Botanical Survey of India 50: 129-146.

MITRA G.C., PRASAD R.N. \& A.R. CHOWDHURY 1976. Inorganic salts and differentiation of protocorms in seed callus of an orchid and corelated changes in its free amino acid content. Indian Journal of Experimental Biology 14: 350-351.

NAG S. \& S. KUMARIA 2018. In silico characterization and transcriptional modulation of phenylalanine ammonia lyase (PAL) by abiotic stresses in the medicinal orchid Vanda coerulea Griff. ex Lindl. Phytochemistry 156: 176-183. https://doi.org/10.1016/j.phytochem. 2018.09.012

NAGARAJU V. \& V.A. PARTHASARATHY 1994. Propagation of Phaius tankervillae using seed and protocorm explants. The Journal of the Orchid Society of India 8: 77-78.

NAGARAJU V. \& R.C. UPADHAYAYA 2001. In vitro morphogenetic response of Cymbidium PLBs to three basal media and activated charcoal. The Journal of the Orchid Society of India 15: 59-64.

NAGARAJU V., DAS S.P., BHUTIA P.C. \& R.C. UPADHAYA 2002. In vitro multiplication of Cymbidium hybrid. The Journal of the Orchid Society of India 16: 25-28.

NAGARAJU V., DAS S.P., BHUTIA P.C. \& R.C. UPADHAYA 2003. Effect of media and BAP on protocorms of Cymbidium and Cattleya. The Journal of the Orchid Society of India 17: 67-72.

NAGARAJU V., DAS S.P., BHUTIA P.C. \& R.C.
UPADHAYA 2004. In vitro multiplication of Dendrobium chrysotoxum and two Dendrobium crosses (D. nobile $x$ D. nobile Var. alba and D. nobile $x D$. heterocarpum) through embryo culture. The Journal of the Orchid Society of India 18: 47-51.

NARAYANAN M.K.R., T. SHAJU, C.N. SUNIL, A.K. ABDUSSALAM \& V.A. JALEEL 2013. Orchids of Wayanad. Lead Books, Calicut.

NAYAK N.R., PATNAIK S. \& S.P. RATH 1997. Direct shoot regeneration from foliar explants of an epiphytic orchid, Acampe praemorsa (Roxb.) Blatter and McCann. Plant Cell Reports 16: 583-586. https://doi.org/10.1007/ BF01142328

NAYAK N.R., RATH S.P. \& S. PATNAIK 1998. High frequency plant regeneration from alginate encapsulated protocorm-like bodies of Spathoglottis plicata Bl., a terrestrial orchid. Phytomorphology 48: 179-186.

NG C.Y. \& N.M. SALEH 2011. In vitro propagation of Paphiopedilum orchid through formation of protocorm like bodies. Plant Cell, Tissue and Organ Culture 105: 193-202. https://doi.org/10.1007/s11240-010-9851-0

PANDA A.K. \& D. MANDAL 2013. The folklore medicinal orchids of Sikkim. Ancient Science of Life 33: 92-96.

PANDE S., SANT N., VISHWARAO V. \& M.N. DATAR 2010. Wild orchids of Northern Western Ghats (including Maharashtra, Goa and Belgaum). Ela Foundation, Pune, India.

PANDEY R.P. \& P.G. DIWAKAR 2008. An integrated check-list of flora of Andaman and Nicobar Islands, India. Journal of Economic and Taxonomic Botany 32: 403500 .

PANGTEY Y.P.S., SAMANT S.S. \& G.S. RAWAT 1991. Orchids of Kumaun Himalaya. Bishen Singh Mahendra Pal Singh, Dehradun.

PANT B. \& S. SWAR 2011. Micropropagation of Cymbidium iridiodes D.Don. The Journal of the Orchid Society of India 25: 9-12.

PANT B., SWAR S. \& A. KARANJEET 2008. Micropropagation of Coelogyne cristata Lindl. The Journal of the Orchid Society of India 22: 45-48.

PARVEEN I., SINGH H.K., RAGHUVANSHI S., PRADHAN U.C. \& S.B. BABBAR 2012. DNA barcoding of endangered Indian Paphiopedilum species. Molecular Ecology Resources 12: 82-90. https://doi.org/ 10.1111/j.1755-0998.2011.03071.x

PARVEEN I., SINGH H.K., MALIK S., RAGHUVANSHI S. \& S.B. BABBAR 2017. Evaluating five different loci (rbc L, rpo B, rpo C1, matK, and ITS) for DNA barcoding 
of Indian orchids. Genome 60: 665-671. https://doi.org/ 10.1139/gen-2016-0215

PATHAK P., PIRI H., VIJ S.P., MAHANT K.C. \& S. CHAUHAN 2011. In vitro propagation and mass scale multiplication of a critically endangered epiphytic orchid, Gastrochilus calceolaris (Buch.-Ham. ex J.E.Sm.) D.Don. using immature seeds. Indian Journal of Experimental Biology 49(9): 711-716.

PATHAK P., VERMA S., PRAKASH A. \& K.C. MAHANT 2017. Regeneration competence of an ornamentally important epiphytic orchid, Rhynchostylis gigantea (Lindl.) Ridl. through leaf segments: a study in vitro. The Journal of the Orchid Society of India 31: 97-101.

PAUL S., KUMARIA S. \& P. TANDON 2012. An effective nutrient medium for asymbiotic seed germination and large-scale in vitro regeneration of Dendrobium hookerianum, a threatened orchid of Northeast India. AoB Plants 2012: 1-7. https://doi.org/10.1093/ aobpla/plr032

PHUKAN S. 2011. The genus Cleisostoma Blume (Orchidaceae) in India. Nelumbo 53: 161-182.

PIRIA R.S., RAJMOHAN K. \& K.B. SONI 2005. Agrobacterium mediated genetic transformation in Dendrobium. The Journal of the Orchid Society of India 19: 57-61.

PIYATHI A.N. \& H.N. MURTHY 1995. In vitro seed germination and seedling development of Dendrobium ovatum (Willd.) Krunzl. The Journal of the Orchid Society of India 9(1): 69-74.

PRADHAN M. 2005. 100 Sikkim Himalayan Orchids. Spenta Multimedia, Mumbai.

PRADHAN U.C. 1976. Indian orchids: guide to identification $\&$ culture. Volume 1. Bharat Lithographing Co. Calcutta.

PRADHAN U.C. 1979. Indian orchids: guide to identification $\&$ culture. Volume 2. Thomson Press (India) Ltd., Faridabad.

PRAIN D. 1903. Bengal Plants. Volume 1. West, Newman and Co., London. (Reprinted 1963) Botanical Survey of India, Kolkata.

PRASAD K.S., KARUPPUSAMY \& T. PULLAIAH 2019. Orchids of Eastern Ghats. Scientific Publishers, Jodhpur.

RAIZADA M.B., NAITHANI H.B. \& H.O. SAXENA 1981. Orchids of Mussoorie. Bishen Singh Mahendra Pal Singh, Dehradun.

RAHAMTULLA M., PRADHAN U.C., ROY A.K., RAMPILLA V. \& S.M. KHASIM 2020. Ethnomedicinal aspects of some orchids from Darjeeling Himalaya, India.
In: KHASIM S.M., HEGDE S.N., GONZÁLEZARNAO M.T. \& K. THAMMASIRI (eds.), Orchid biology: Recent trends \& challenges. Springer, Singapore. pp. 451-472. https://doi.org/10.1007/978-981-32-94561_23

RAJENDRAN A., RAO N.R., KUMAR K.R. \& A.N. HENRY 1997. Some medicinal orchids of southern India. Ancient Science of Life 17: 10.

RAJU V.S., REDDY C.S., REDDY K.N., RAO K.S. \& B. BAHADUR 2008. Orchid wealth of Andhra Pradesh, India. Proceedings of AP Academic Science 12: 180-192.

RAJULU G., SURYANARAYANAN T.S. \& S. TANGJANG 2016. Endophytic fungi of orchids of Arunachal Pradesh, north eastern India. Current Research in Environmental \& Applied Mycology 6: 293-299. https:/ doi.org/10.5943/cream/6/4/7

RAMESH G., RAMUDU J., KHASIM S.M. \& K. THAMMASIRI 2016. Genetic diversity in some Indian Bulbophyllinae (Orchidaceae) with reference to ecological adaptability and phylogenetic significance. Acta Horticulturae 1167: 187-196. https://doi.org/ 10.17660/ActaHortic.2017.1167.29

RAO A.N. 1967. Histogenesis and organogenesis in orchid seedlings. In: JOHRI B.M. (ed.), Seminar on plant cell, tissue and organ cultures. University of Delhi, New Delhi. pp. 71-74.

RAO A.N. 1986. Orchid flora of Arunachal Pradesh- a conspectus. In: Vij S.P. (ed.), Biology, conservation and culture of orchids. East West Press Pvt. Ltd., New Delhi. pp. 323-349.

RAO A.N. 2007. Orchid flora of Northeast India - an upto-date analysis. Bulletin of Arunachal Forest Research 23: 6-38.

RAO A.N. 2010. Orchid flora of Arunachal Pradesh - an update. Bulletin of Arunachal Forest Research 26: 82-110.

RAO C.S. \& SINGH S.K. 2015. Wild Orchids of Meghalaya a pictorial guide. Meghalaya Biodiversity Board, Shillong.

RAO S.R. 2020. Status of genetic diversity and its characterization in genus Bulbophyllum (Orchidaceae) from north-eastern India. In: KHASIM S.M., HEGDE S.N., GONZÁLEZ-ARNAO M.T. \& K. THAMMASIRI (eds.), Orchid biology: Recent trends \& challenges. Springer, Singapore. pp. 149-154. https:// doi.org/10.1007/978-981-32-9456-1_8

RAO S.R., RAJKUMARI K., SHARMA S.K., KUMARIA S. \& P. TANDON 2013. Karyo-morphological characterization of natural genetic variation in some threatened Cymbidium species of Northeast India. Caryologia 63: 99-105. https://doi.org/10.1080/ 00087114.2010 .10589713 
RAO T.A. 1998. Conservation of wild orchids of Kodagu in the Western Ghats. The Karnataka Association for the Advancement of Science, Bangalore.

RATHORE S. 1983. A taxonomic revision of the orchid genera Calanthe R.Br. \& Cymbidium Sw. in India. Ph.D. Thesis (unpublished), University of Kolkata, West Bengal.

ROXBURGH W. 1832. Flora Indica. ed. 2. Parbury, Allen and Co., London.

ROY J. \& N. BANERJEE 2003. Induction of callus and plant regeneration from shoot-tip explant of Dendrobium fimbriatum Lindl. var. oculatum Hk.f. Scientia Horticulturae 97: 333-340. https://doi.org/10.1016/S03044238(02)00156-5

ROY S.C., MOITRA K. \& D. DE SARKER 2017. Assessment of genetic diversity among four orchids based on ddRAD sequencing data for conservation purposes. Physiology and Molecular Biology of Plants 23: 169-183. https://doi.org/10.1007/s12298-016-0401-z

SABAPATHY C.M. 2013. Taxonomic studies on the genus Dendrobium Sw. (Orchidaceae) in India. Ph.D. Thesis (unpublished), Kalyani University, West Bengal.

SAHA D. \& A.N. RAO 2006. Studies on endophytic mycorrhiza of some selected orchids of Arunachal Pradesh-1. Isolation and identification. Bulletin of Arunachal Forest Research 22: 9-16.

SAIPRASAD G.V.S. \& R. POLISETTY 2003. Propagation of three orchid genera using encapsulated protocormlike bodies. In vitro Cellular and Developmental BiologyPlant 39: 42-48. https://doi.org/10.1079/IVP2002360

SANTAPAU H. \& Z. KAPADIA 1966. The Orchids of Bombay. Government of India Press, Kolkata.

SATHIYADASH K., MUTHUKUMAR T., MURUGAN S.B., SATHISHKUMAR R., UMA E., JAISON E. \& P. PRIYADHARSINI 2013. In vitro asymbiotic seed germination, mycorrhization and seedling development of Acampe praemorsa (Roxb.) Blatt. \& Mc Cann, a common South Indian orchid. Asian Pacific Journal of Rep 2: 114-118.

SATHIYADASH K., MUTHUKUMAR T., MURUGAN S.B., SATHISHKUMAR R. \& R.R. PANDEY 2014. In vitro symbiotic seed germination of South Indian endemic orchid Coelogyne nervosa. Mycoscience 55: 18389. https://doi.org/10.1016/j.myc.2013.08.005

SCHUITEMAN A., KAILASH B.R., SHRESTHA U.B. \& N. SWAMY 2021. A checklist of the orchidaceae of India. Missouri Botanical Garden Press, Missouri.

SEENI S. \& P.G. LATHA 1992. Foliar regeneration of endangered red vanda, Renanthera imshootiana Rolfe. (Orchidaceae). Plant Cell, Tissue and Organ Culture 29: 169-172. https://doi.org/10.1007/BF00034349
SEENI S. \& P.G. LATHA 2000. In vitro multiplication and eco-rehabilitation of the endangered blue vanda. Plant Cell, Tissue and Organ Culture 61: 1-8. https://doi.org/ 10.1023/A:1006444614657

SEIDENFADEN G. \& C.M. ARORA 1982. An enumeration of the orchids of the north-western Himalaya. Nordic Journal of Botany 2: 7-27. https:// doi.org/10.1111/j.1756-1051.1982.tb01431.x

SELOSSE M.A. 2014. The latest news from biological interactions in orchids: in love, head to toe. New Phytologist 202: 337-340.

SENTHILKUMAR S. 2003. Mycorrhizal fungi of endangered orchid species in Kolli, a part of Eastern Ghat's, south India. Lankesteriana 7: 155-156.

SENTHILKUMAR, S. \& K.V. KRISHNAMURTHY 1998. A cytochemical study on the mycorrhizae of Spathoglottis plicata. Biologia Plantarum 41: 111-119. https://doi.org/ 10.1023/A:1001724803177

SHADANG R., DWIVEDI P. \& S.N. HEGDE 2007. Shoot formation through in vitro culture of axillary buds in Ascocentrum ampullaceum (Roxb.) Schltr. The Journal of the Orchid Society of India 21: 71-74.

SHADANG R., DWIVEDI P. \& S.N. HEGDE 2009. Regeneration competence of Hygrochilus parishii inflorescence segments and axillary buds: a study in vitro. The Journal of the Orchid Society of India 23: 75-78.

SHARMA A.K. \& A.K. CHATTERJI 1961. The chromosome numbers of a few more orchid genera. Current Science 30: 75.

SHARMA J. 1998. Studies on Vanda: Effect of age of capsule (pods) on in vitro seed germination. The Journal of the Orchid Society of India 12: 43-45.

SHARMA S.K. \& P. TANDON 1990. Asymbiotic germination and seedling growth Cymbidium elegans Lindl. and Coelogyne punctulate Lindl. as influenced by different carbon sources. The Journal of the Orchid Society of India 4: 149-159.

SHARMA S.K., TANDON P. \& R.R. MISHRA 1991. Vitamins as related to axenic seed germination and seedling growth of Cymbidium elegans Lindl. and Coelogyne punctulata Lindl. The Journal of the Orchid Society of India 5: 25-28.

SHARMA S.K., RAJKUMARI K., KUMARIA S., TANDON P. \& S.R. RAO 2010. Karyo-morphological characterization of natural genetic variation in some threatened Cymbidium species of Northeast India. Caryologia 63: 99-105. https://doi.org/10.1080/ 00087114.2010.10589713

SHARMA S.K., KUMARIA S., TANDON P. \& S.R. RAO 2011. Single primer amplification reaction (SPAR) reveals inter-and intra-specific natural genetic variation 
in five species of Cymbidium (Orchidaceae). Gene 483: 54-62. https://doi.org/10.1016/j.gene.2011.05.013

SHARMA S.K., DKHAR J., KUMARIA S., TANDON P. \& S.R. RAO 2012a. Assessment of phylogenetic interrelationships in the genus Cymbidium (Orchidaceae) based on internal transcribed spacer region of rDNA. Gene 495: 10-15. https://doi.org/10.1016/ j.gene.2011.12.052

SHARMA S.K., KUMARIA S., TANDON P. \& S.R. RAO 2012b. Comparative karyomorphological study of some Indian Cymbidium Swartz, 1799 (Cymbidieae, Orchidaceae). Comparative Cytogenetics 6: 453. https:// doi.org/10.3897/compcytogen.v6i4.3461

SHARMA S.K., KUMARIA S., TANDON P. \& S.R. RAO 2013a. Assessment of genetic variation and identification of species-specific ISSR markers in five species of Cymbidium (Orchidaceae). Journal of Plant Biochemistry and Biotechnology 22: 250-255. https://doi.org/10.1007/ s13562-012-0127-0

SHARMA S.K., SINGH S.K., KUMAR R. \& A.A. MAO 2013b. A compendium of monopodial orchids of Meghalaya. Keanean Journal of Science 2: 93-106.

SHARON M. \& G. VASUNDHARA 1990. Micropropagation of Dendrobium Joannie Ostenhault. The Journal of the Orchid Society of India 4: 145-148.

SHEELAVANTMATH S.S., MURTHY H.N., PYATI A.N., KUMAR H.G. \& B.V. RAVISHANKAR 2000. In vitro propagation of endangered orchid Geodorum densiflorum (Lam.) Schltr. through rhizome section culture. Plant Cell, Tissue and Organ Culture 60: 151154. https://doi.org/10.1023/A:1006426905052

SHIVA K.N., NAIR S.A. \& R.P. MEDHI 2003. Orchid diversity and its conservation in Bay Islands. The Journal of the Orchid Society of India 17: 57-62.

SHUKLA B.K., SINGH P. \& A.S. CHAUHAN 1998. Orchid diversity in Sikkim and its conservation. The Journal of the Orchid Society of India 12: 53-76.

SIBIN N.T. \& A. GANGAPRASAD 2016. Development of in vitro propagation protocol for rapid and mass propagation of Coelogyne nervosa A.Rich., an endemic orchid of the southern Western Ghats using immature seeds. The Journal of the Orchid Society of India 30: 37-42.

SIBIN N.T., GANGAPRASAD A. \& S. ANJUSHA 2014. Effect of different organic additives on in vitro asymbiotic germination of Arundina graminifolia (D.Don) Hochr., an exquisite rare orchid. The Journal of the Orchid Society of India 28: 61-66.

SINGH D.K., WADHWA B.M. \& K.P. SINGH 1990. A conspectus of orchids of Mizoram: their status and conservation. The Journal of the Orchid Society of India 4: 51-64.
SINGH H.K., PARVEEN I., RAGHUVANSHI S. \& S.B. BABBAR 2012. The loci recommended as universal barcodes for plants on the basis of floristic studies may not work with congeneric species as exemplified by DNA barcoding of Dendrobium species. BMC Research Notes 5: 1-11. https://doi.org/10.1186/1756-0500-5-42

SINGH S.K., AGRAWALA D.K., JALAL J.S., DASH S.S., MAO A.A. \& P. SINGH 2019. Orchids of India - a pictorial guide. Botanical Survey of India, Kolkata.

SINHA P. \& S.K. ROY 2004. Regeneration of an indigenous orchid Vanda teres (Roxb.) Lindl. through in vitro culture. Plant Tissue Culture 14: 55-61.

SINHA S.K., HEGDE S.N. \& G. BHOWMIK 2001. Differential effect of gamma radiation on morphogenesis of PLBs of Renades 'Arunodaya' hybrid and its parent species Aerides rosea and Renanthera imschootiana. The Journal of the Orchid Society of India 15: 39-48.

SREEDHAR R.V., VENKATACHALAM L., ROOHIE K. \& N. BHAGYALAKSHMI 2007. Molecular analyses of Vanilla planifolia cultivated in India using RAPD and ISSR markers. Orchid Science and Biotechnology 1: 29-33.

SRIVASTAVA S., KADOOKA C. \& J.Y. UCHIDA 2018. Fusarium species as pathogen on orchids. Microbiological research 207: 188-195. https://doi.org/10.1016/ j.micres.2017.12.002

SWAMI N. 2016. Terrestrial orchids. Thomson Press India Ltd., Faridabad.

SWAMI N. 2017. Orchids of Ziro. Thomson Press India Ltd., Faridabad.

TALUKDAR A. 2001. Multiple shoot induction in Dendrobium aphyllum Roxb. The Journal of the Orchid Society of India 15: 35-38.

TANDON R. \& I. BHARDHWAJ 2012. Reproductive strategies in Orchidaceae. The Journal of the Orchid Society of India 26: 35-48.

TEMJENSANGBA \& C.R. DEB 2005. Regeneration of plants from in vitro raised leaf explants of Cleistostoma racimeferum Lindl. Indian Journal Experimental Biology 43: 377-381.

THAKUR N. \& R. KAUR 2013. Molecular characterization of Dactylorhiza hatagirea (D.Don) Soo-a critically endangered medicinal orchid. International Journal of Medicinal and Aromatic Plants 3: 184-190.

TSERING J. \& K. PRASAD 2020. Spathoglottis arunachalensis (Orchidaceae), a new species from Arunachal Pradesh, India. Phytotaxa 432: 289-295. https://doi.org/10.11646/phytotaxa.432.3.6

TUYAMA T. 1966. Orchidaceae. In: HARA H. (ed.), Flora of Eastern Himalaya. University of Tokyo Press, Tokyo. pp. 424-452. 
TUYAMA T. 1971. Orchidaceae. In: HARA H. (ed.), Flora of Eastern Himalaya Second Report. University of Tokyo Press, Tokyo. pp. 176-196.

VAN RHEEDE H.A. 1692. Hortus Malabaricus Volume 11. Joannis \& D.V. Joannis, Amsterdam.

VAN RHEEDE H.A. 1693. Hortus Malabaricus Volume 12. Joannis \& D.V. Joannis, Amsterdam.

VASUNDHARA, PATHAK P. \& A. PRAKASH 2019. In vitro shoot induction and regeneration potential of floral buds in Crepidium acuminatum (D.Don) Szlach., a medicinal ayurvedic plant from north-western Himalayas. The Journal of the Orchid Society of India 33: 43-48.

VENKAIAH M., RAO J.P., NAIDU M.T., PRAMEELA R., RAO P.J. \& S.B. PADAL 2020. Orchid diversity in the Eastern Ghats of northern Andhra Pradesh, India. In: KHASIM S.M., HEGDE S.N., GONZÁLEZARNAO M.T. \& K. THAMMASIRI (eds.), Orchid biology: Recent trends \& challenges. Springer, Singapore. pp. 189-206. https://doi.org/10.1007/978-981-32-94561_10

VERMA D., SINGH S.K. \& A.A. MAO 2013. Notes on diversity and distribution of tribe Orchideae in Meghalaya. Keanean Journal of Science 2: 83-92.

VIJ S.P. 1993. Regeneration response of orchid roots: A study in vitro. The Journal of the Orchid Society of India 7: 61-72.

VIJ S.P. \& P. PATHAK 1988. Asymbiotic germination of the saprophytic orchid, Cymbidium macrorhizon: A study in vitro. The Journal of the Orchid Society of India 2: $25-32$.

VIJ S.P. \& P. PATHAK 1989. Micropropagation of Dendrobium chrysanthum Wall. through pseudobulb segments. The Journal of the Orchid Society of India 3: 25-28.

VIJ S.P. \& P. PATHAK 1990. Micropropagation of orchids through leaf segments. The Journal of the Orchid Society of India 4: 69-88.

VIJ S.P. \& P. KAUR 1992. Regeneration potential of foliar peels: Rhynchostylis retusa. The Journal of the Orchid Society of India 6: 71-74.

VIJ S.P. \& S. AGGARWAL 2003. Regeneration competence of foliar explants: Vanda coerulea Griff. The Journal of the Orchid Society of India 17: 73-78.

VIJ S.P., SOOD A., SHARMA M. \& K.K. PLAHA 1984. Propagation of Rhynchostylis retusa Bl. (Orchidaceae) by direct organogenesis from leaf segments. Botanical Gazzette 145: 210-214. https://doi.org/10.1086/337448

VIJ S.P., SOOD A. \& M. SHARMA 1986. In vitro leaf segment culture of Vanda testacea (Lindl.) Reichb.f. (=V. parviflora Lindl.) (Orchidaceae). Current Science 55: 1100-1101.

VIJ S.P., PATHAK P. \& M. SHARMA 1987. On the regeneration potential of Rhynchostylis retusa root segments: a study in vitro. The Journal of the Orchid Society of India 1: 71-74.

VIJ S.P., SOOD A. \& P. PATHAK 1989. On the utility of rhizome segments in micropropagating Eulophia hormusjii Duth. The Journal of the Orchid Society of India 3: 41-45.

VIJ S.P., KONDO K. \& P. PATHAK 1994. Regeneration potential of Cymbidium pendulum (Roxb.) Sw. nodal explants - a study in vitro. The Journal of the Orchid Society of India 8: 19-23.

VIJ S.P., PATHAK P. \& K.C. MAHANT 1995. Green pod culture of therapeutically important species Dactylorhiza hatagirea (D.Don) Soo. The Journal of the Orchid Society of India 9: 7-12.

VIJ S.P., PATHAK P. \& A. KHER 1997. Regeneration response of Rhynchostylis gigantea inflorescence segments: a study in vitro. The Journal of the Orchid Society of India 11: 75-78.

VIJ S.P., KHER A. \& P. PATHAK 2000. Regeneration competence of Bulbophyllum careyanum (Hook.) Spreng. pseudobulb segments. The Journal of the Orchid Society of India 14: 47-55.

VIJ S.P., VERMA J. \& C.S. KUMAR 2013. Orchids of Himachal Pradesh. Bishen Singh Mahendra Pal Singh, Dehradun.

VYAS S., GUHA S., BHATTACHARYA M. \& I.U. RAO 2009. Rapid regeneration of plantlets of Dendrobium lituiflorum Lindl. (Orchidaceae) by using banana extract. Scientia Horticulturae 121: 32-37. https://doi.org/ 10.1016/j.scienta.2009.01.012

WATERMAN R.J., BIDARTONDO M.I., STOFBERG J., COMBS J.K., GEBAUER G., SAVOLAINEN V., BARRACLOUGH T.G. \& A. PAUW 2011. The effects of above-and belowground mutualisms on orchid speciation and coexistence. The American Naturalist 177: 54-68. https://doi.org/10.1086/657955 